\title{
Beyond the blame game: a restoration pathway reconciles ecologists' and local leaders' divergent models of seasonally dry tropical forest degradation
}

\author{
$\underline{\text { Andrea K. Jara-Guerrero }}^{1}$, Diana Maldonado-Riofrió ${ }^{1}$, Carlos I. Espinosa $^{1}$ and David H. Duncan $^{2}$
}

\begin{abstract}
An understanding of ecosystem dynamics under different scenarios of degradation is required to reverse ecological degradation and identify restoration priorities. Such knowledge can be the result of scientific investigation, but important insight can also reside in observant local land managers. In seasonally dry tropical forests in southern Ecuador, recent decades have seen important advances in the knowledge of the biodiversity values of these forests, but the available data have not yet been integrated and translated into tools that support managers in deciding restoration measures. One powerful framework to organize and communicate information about ecosystem degradation and recovery dynamics is the state-transition model. We generated such a model by combining ecologist and local knowledge obtained through an adaptation of the Stanford/SRI expert elicitation protocol. Through this information, we identified five forest states with specific attributes of vegetation, human pressures, and restoration needs. Ecologists and locals agreed on the restoration actions but partially disagreed on the causes of degradation. Whereas ecologists considered that grazing management, often introduced with or after logging, was the catalyst for a transition to degraded states, locals attributed those transitions to the effects of logging alone. Importantly, however, both ecologists and locals considered that exclusion of livestock grazing was a necessary action to promote ecological recovery. A forward-looking strategy focusing on objectives for ecosystem recovery and ecosystem management for biodiversity and human well-being might be more successful than strategies that emphasize or seek to attribute responsibility for degradation.
\end{abstract}

Key Words: conservation status; desertification; dry forest; drylands; forest management; state-transition model

\section{INTRODUCTION}

Ecological degradation and biodiversity loss, amplified by accelerating global change, highlight the need to manage ecosystems actively to maintain or recover the ecosystem services that support human well-being (Hobbs et al. 2011, Bennett et al. 2015). Despite the efforts of ecologists to study the dynamics of ecosystems and the species and functions that define them, over many decades in some cases, we still lack an understanding of the complex dynamics of most ecosystems that would permit us to intervene confidently in their management (DeFries and Nagendra 2017). Alarmingly, the scientific understanding we do have is not always considered in the conservation or restoration initiatives proposed by decision makers (Cook et al. 2010).

The dynamics of dryland ecosystems (as in Maestre et al. 2012) are studied relatively rarely, making it even more difficult to take informed management and recovery actions (James et al. 2013). This lack of research is despite the fact that drylands account for approximately $42 \%$ of the terrestrial surface of the planet and support a large part of the world's population (James et al. 2013, de la Cruz et al. 2017). These ecosystems are inherently subject to periodic environmental extremes and, therefore, are at risk of irreversible degradation due to anthropogenic pressures on their ecological function (Reynolds et al. 2007, Bestelmeyer et al. 2015).

Ecological communities comprise complex biotic and abiotic interactions, which may span large spatial areas and long time periods. The management of an ecosystem, therefore, requires that this inherent complexity be simplified through model representations tuned to a specific question or objective (Starfield 1997). One powerful framework to organize and communicate information about ecosystem degradation and recovery dynamics is the state-transition model (STM; Westoby et al. 1989, Bestelmeyer et al. 2017). The core of an STM consists of qualitative or quantitative descriptions of discrete ecosystem states, based on composition, structure, and function, that could occur as a function of management and its interaction with the system's biotic and abiotic drivers. In addition to justifying the states, the model should identify both the causes of observed or posited transitions between states and the restrictions to recovery of particular communities (Bestelmeyer et al. 2017).

The STM model easily accommodates definitions of irreversible transitions and alternative or novel states; thus, it is an appropriate tool with which to represent nonlinear ecosystem dynamics (Oliva et al. 2016) and even ecosystem collapse (Bland et al. 2016). STMs range from simplified conceptual forms (e.g., Westoby et al. 1989, Eastburn et al. 2017) to complex quantitative forms (e.g., Rumpff et al. 2011), disparate ecological contexts such as habitats (Wilkinson et al. 2005, McIntyre and Lavorel 2007, Grechi et al. 2014, Young et al. 2014, Tarrasón et al. 2016) or guilds (Radford et al. 2014), and at small (Spooner and Allcock 2006, Oliva et al. 2016) and large scales (Steele et al. 2012). Additionally, STMs are graphic models with strong communication potential (Bestelmeyer et al. 2017). They can be used to moderate false expectations of restoration to "pristine" conditions (Laycock 1991), and to highlight undesirable states and show approaches that can be taken to prevent their occurrence (Westoby et al. 1989, Whalley 1994, Bland et al. 2016).

Most ecological models, including STMs, are constructed from knowledge and observations generated under a scientific paradigm, but there is growing interest in incorporating local

${ }^{1}$ Departamento de Ciencias Biológicas, Universidad Técnica Particular de Loja, Ecuador, ${ }^{2}$ School of BioSciences, University of Melbourne, Australia 
knowledge (e.g., Bestelmeyer et al. 2017, Avirmed et al. 2018, Bélisle et al. 2018). Scientific data and opinion offer in repeatability and structure to treat observational biases (Knapp et al. 2011), but often lack in temporal depth. By contrast, a perceptive local person may observe the environment closely for a long period of time, which may offer unique insight (Lynam et al. 2002, Duncan et al. 2010, Mistry and Berardi 2016, Schulz et al. 2019). In addition to the specific insight that local knowledge may contribute to the conception and construction of ecological models, research outputs founded in participatory approaches can result in products and tools that are accessible, credible, and useful for managers and other stakeholders (Cash et al. 2003, Prell et al. 2007, Reid et al. 2016).

We drew on ecological and local expertise to formulate a STM for seasonally dry tropical forests (SDTF) in southern Ecuador. Dry tropical forests are named for, and driven by, the strongly marked and contrasting seasonality of a short wet and humid period and a long dry period (e.g., Murphy and Lugo 1986, Espinosa et al. 2012). This forest type dominates the Equatorial Pacific Ecoregion, which is considered a global conservation priority because of an exceptionally large number of endemic species (Dinerstein et al. 1995, Davis et al. 1997, Myers et al. 2000, Olson and Dinerstein 2002). These forests are integral to the Bosque Seco Biosphere Reserve and the Bosques de Paz Transboundary Biosphere Reserve, which incorporates neighboring landscapes of northern Peru (http://www.unesco. org/new/en/natural-sciences/environment/ecological-sciences/biospherereserves/).

In recent years, there have been important advances in the knowledge of the SDTF in southern Ecuador, especially in floristic and biogeographical terms (Aguirre Mendoza and Kvist 2005, Cueva Ortiz and Chalán 2010, Portillo-Quintero and Sánchez-Azofeifa 2010, Espinosa et al. 2011, 2012, 2016, JaraGuerrero et al. 2011, 2015, 2018, Aguirre Mendoza and GeadaLopez 2017, Cueva Ortiz et al. 2019). However, this information has not yet been integrated in such a way that ecologists and managers can anticipate risks to the conservation of the SDTF ecosystem (Escribano-Avila et al. 2017). In our STM, we organized the current knowledge and identified areas of discrepancy and commonality between ecologists and knowledgeable local people with regard to the processes of disturbance and possibilities of recovery of SDTF. By highlighting competing ideas, the model can support the development of a management agenda targeted at resolving knowledge gaps that may impede the conservation, successful restoration, and sustainable management that supports the wise use of resources and maintenance of ecosystem functionality.

\section{METHODS}

\section{Study area}

The study is located in an area of approximately $875 \mathrm{~km}^{2}$ of SDTF in Zapotillo County, Loja Province, southwestern Ecuador (Fig. 1), between 182 and $835 \mathrm{~m}$ above sea level. The climate is subtropical, with mean annual precipitation of $\sim 500 \mathrm{~mm}$ (Aguirre Mendoza and Kvist 2005) and an average annual temperature of $25.8^{\circ} \mathrm{C}$ (Hurtado 2015). The soils are dominated by entisols $(\sim 98 \%)$, which are young, erodible soils on shallow to steep slopes (Hurtado 2015). The SDTF of Zapotillo varies in composition and relative dominance from semideciduous to deciduous forests according to altitude, topography, and annual mean precipitation (Espinosa et al. 2011). This variation fits within our concept of the "ecological site" (as in Bestelmeyer et al. 2010) and does not interfere with state descriptions and delineation.

Fig. 1. Maps of the study location. (A) Map of the Tumbesian region located in Pacific coastal Ecuador and northern Peru. (B) Location of Zapotillo County, southwestern Ecuador. (C) Map of the remnant forest vegetation of Zapotillo County.
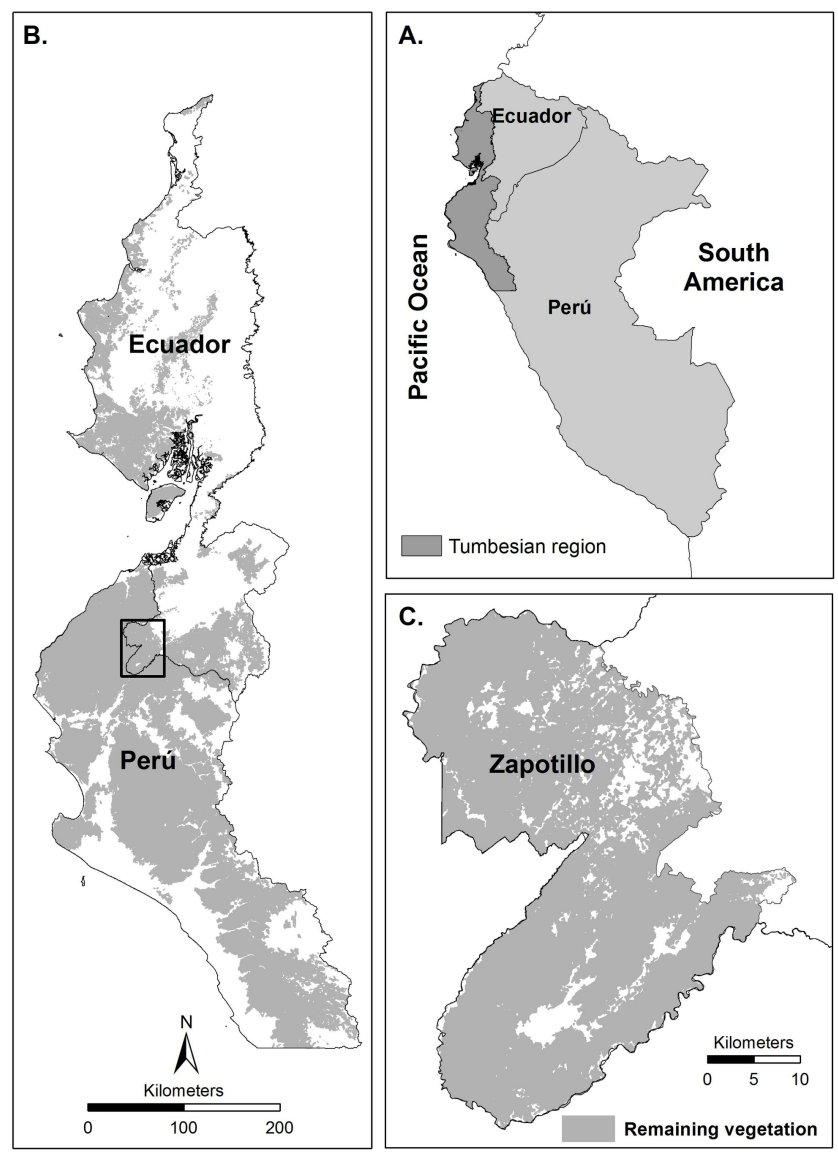

Zapotillo County has 12,312 residents in a total area of $1213 \mathrm{~km}^{2}$, with a population density of 8 people $/ \mathrm{km}^{2}$ in rural areas (INEC 2010). The most significant economic activities for local people are agricultural crop and livestock production (principally goats; INEC 2010), with livestock herding taking place inside the forest in a silvopastoral system (Ochoa et al. 2016). Traditionally, goats range freely into the forest, which provides a low investment of time and resources for their owners. Local recognition of the threats to the conservation values of the forests in the Zapotillo area led to the establishment of private conservation initiatives, which occupy approximately $19 \%$ of Zapotillo County, as well as governmental initiatives, which cover approximately $15 \%$ of the county (Hurtado 2015). We focused on extant forest remnants that vary in their history of livestock activity. 


\section{Model elicitation and development}

We generated the conceptual STM from the opinion of eight ecological experts, hereafter ecologists, and six knowledgeable local people, hereafter locals. Our approach adapted the initial four steps of the Stanford/SRI expert elicitation protocol (van der Sluijs et al. 2004): (1) identifying and selecting experts, (2) motivating the subject, (3) structuring, and (4) eliciting uncertainty and limits from ecologists and locals regarding their opinions.

We selected ecologists with professional training in biology, ecology, environmental management, or forestry; technical and at least five years of field experience in the SDTF of Zapotillo; and authorship of publications relevant to the study area (Appendix 1). Applying the chain sampling strategy (Newing 2011), the first identified ecologists were asked to refer other ecologists. This process yielded ecologists from three institutions: Universidad Técnica Particular de Loja, Universidad Nacional de Loja, and Nature and Culture International (a nongovernmental organization). To identify locals, we used the chain sampling strategy, beginning with a contact who collaborates with the three aforementioned institutions. We selected locals using two criteria: living in the study area for at least 20 years, and having a primary activity based on the use of the forest ecosystem for livestock herding. Some interviewees also undertake hunting and subsistence agriculture in the forest surroundings. Each local was interviewed at his or her home, and all interviews were conducted in Spanish. Paraphrasing indicated in the text was translated by the authorial team.

We sought to make the knowledge of ecologists and local people visible, usable, and comparable (Slottje et al. 2008). The locals' knowledge was also considered ecological in nature, but from a nonscientific, traditional knowledge foundation. What may distinguish scientific and traditional ecological knowledge is debatable (e.g., Agrawal 1995, Raymond et al. 2010), but increasing recourse to elicitation techniques in ecology in response to data gaps (e.g., Johnson et al. 2012, McBride et al. 2012) potentially places scientific and local knowledge on a more even observational footing.

We used semistructured interviews that were previously tested to clarify that they provoked the intended type of response (e.g., Martin et al. 2012). To reduce subjectivity in the interpretation of key STM concepts, we consistently used definitions of forest states, transitions, drivers of transitions, management actions, and risk phases (Table 1) adapted from Rumpff et al. (2011) and Bestelmeyer et al. (2010, 2017). These definitions were provided to participants at the beginning of the interview. For locals, we used alternative nontechnical terms (Table 1). Each interview was recorded with the prior consent of the participant.

We undertook two rounds of interviews. In the first round, we asked participants to identify the different states that they recognize in the forest (Appendix 2). We then asked them to suggest the variables that define those states, as well as the management actions associated with each state. In interviews with locals, we used alternative questions to avoid using technical language (Appendix 2). From these data, we generated preliminary model diagrams representing the states and transitions of the SDTF. Interviewees were encouraged to characterize the variables defining each state, such as species richness or plant cover, and to characterize the change in those variables using quantitative scales. We codified the answers of interviewees following the methods of Newing (2011). That process started with the definition of five categories adapted from Bestelmeyer et al. (2010, 2017): forest states, transitions, duration of drivers, duration of management actions, and risk phase. Within forest states, we defined subcategories of structure, vegetation cover, characteristic species, tree height, functionality, regeneration, and soil. With this codified information, we constructed our STM.

Table 1. Brief description of the key terms used in this study. Terms were adapted from Bestelmeyer et al. $(2010,2017)$ and Rumpff et al. (2011). Alternative, nontechnical terms used with locals are indicated in italic font.

\begin{tabular}{|c|c|}
\hline Term & Definition in state-transition model \\
\hline State / forest type & $\begin{array}{l}\text { States that can be differentiated by changes in } \\
\text { structure and plant composition due to } \\
\text { anthropogenic disturbance actions }\end{array}$ \\
\hline $\begin{array}{l}\text { Reference state / best- } \\
\text { preserved forest }\end{array}$ & $\begin{array}{l}\text { Represents the historical or natural state of } \\
\text { the site, including its range of variation }\end{array}$ \\
\hline $\begin{array}{l}\text { State variables / } \\
\text { characteristics of forest } \\
\text { types }\end{array}$ & $\begin{array}{l}\text { Attributes of structure and composition of } \\
\text { the vegetation used to define the states, } \\
\text { changes in which can indicate or lead to a } \\
\text { transition to another state }\end{array}$ \\
\hline $\begin{array}{l}\text { Transition / changes in } \\
\text { forest types }\end{array}$ & $\begin{array}{l}\text { A change in the state caused by the passing of } \\
\text { a threshold value for one or more state } \\
\text { variables }\end{array}$ \\
\hline Management actions & $\begin{array}{l}\text { The management interventions used to } \\
\text { improve the condition of vegetation in a site }\end{array}$ \\
\hline $\begin{array}{l}\text { Drivers / human activities } \\
\text { that provoke changes in } \\
\text { forest types }\end{array}$ & $\begin{array}{l}\text { Drivers that generate long-term changes and } \\
\text { lead to transitions between states }\end{array}$ \\
\hline $\begin{array}{l}\text { Community phase at } \\
\text { risk / time of highest } \\
\text { susceptibility to changes } \\
\text { in forest type }\end{array}$ & $\begin{array}{l}\text { The phase particularly vulnerable to a } \\
\text { transition to an alternative state; normally it } \\
\text { is defined for the reference state }\end{array}$ \\
\hline
\end{tabular}

In a second phase of interviews, we validated the draft STM through a member checking process (Harper and Cole 2012) involving all ecologists that were previously interviewed. We elicited opinions regarding the validity of the proposed states and additional characteristics of structure, vegetation cover, characteristic species, tree height, functionality, regeneration, or soil, as well as the thresholds that cause changes from one state to another. To elicit variation and limits, we encouraged interviewees to consider and represent uncertainty (Cooke 1991) using maximum and minimum values for each variable in each state. Where possible, the information obtained was complemented with published quantitative information. The results from this phase informed the final STM model.

The sampling unit was each individual, and the analysis did not seek to generate formal consensus (e.g., McBride et al. 2012) but rather to record, consider, and preserve the variation in judgment among ecologists and locals, which can be valuable for exploring uncertain and complex systems (e.g., Granger Morgan et al. 2002). In the results and discussion, where we refer to agreement and disagreement for states and characteristics defining states, the judgement was based on an analysis of the coded responses of the interviewees. They are annotated parenthetically; for example, 
Fig. 2. Forest states of the Zapotillo dry forest ecological site, with variation between the dry and rainy season. State descriptions include vegetation structure, natural regeneration, and soil characteristics. The letters in parentheses indicate the group of stakeholders that mentioned each characteristic: $\mathrm{E}=$ ecologists, $\mathrm{L}=$ locals, and $\mathrm{C}=$ consensus between both groups.

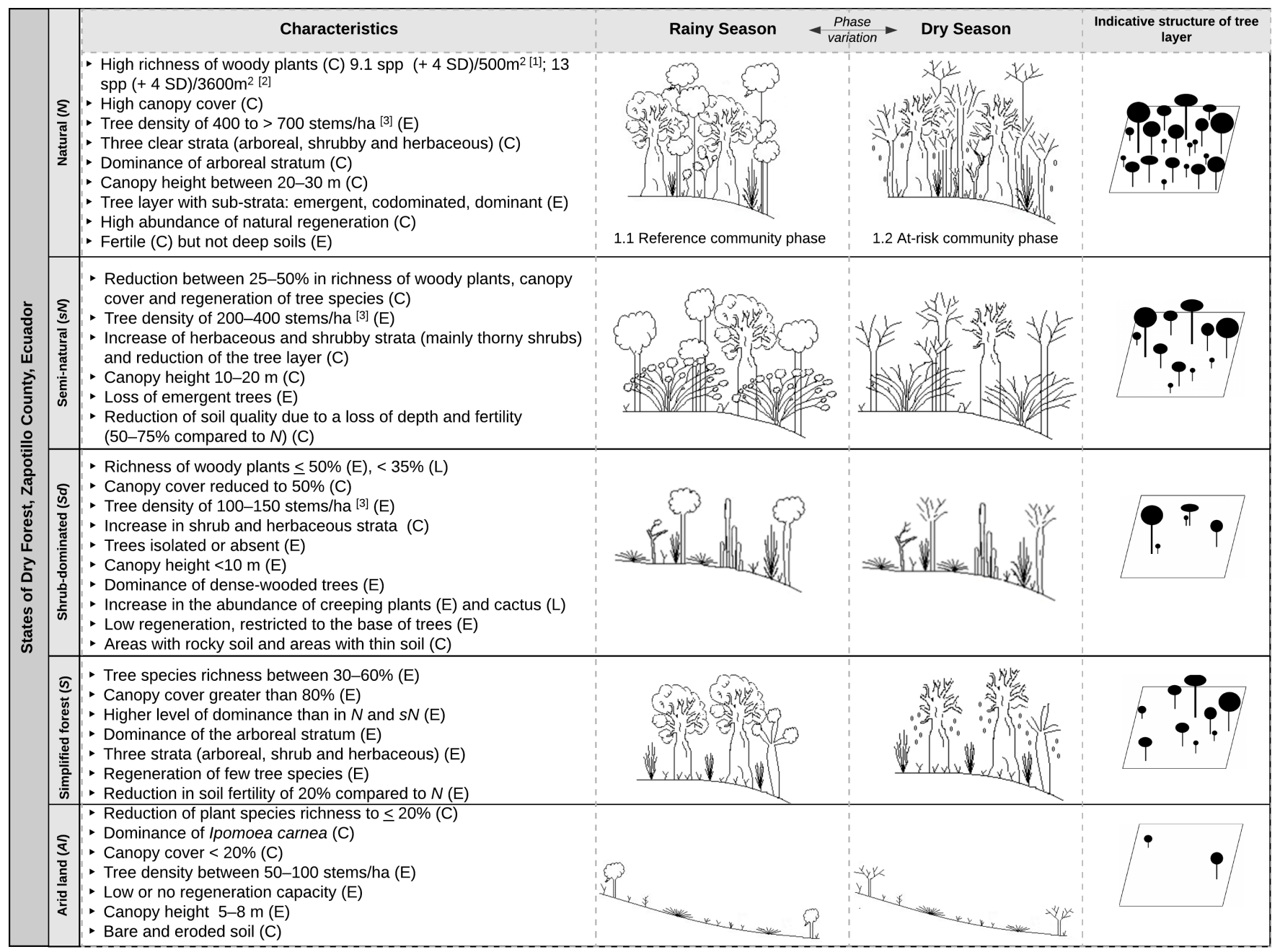

[1] Espinosa et al 2011, [2] Cueva Ortiz et al 2019, [3] Cabrera et al. 2002

E 5/8 denotes that the opinion of five out of eight ecologists coincided on a particular detail or idea.

\section{RESULTS}

Five forest states were identified on the basis of structural characteristics and species composition (Fig. 2). We applied the names: natural $(\mathrm{N})$, seminatural $(\mathrm{sN})$ shrub-dominated $(\mathrm{Sd})$, simplified (S) and arid land (Al). Detailed observations regarding the states are summarized in Fig. 2; here, we highlight only the results most pertinent to our discussion.

\section{Natural state}

A natural or reference state was defined by all participants as forest with high structural diversity across three strata, plus emergent trees, high tree density, and high richness of woody plant species. The locals referred to this state as bosque tupido, a reference to its closely woven upper strata. Natural regeneration was considered to be abundant (E 8/8; L 6/6), attributed to a high density of seeds stored in the soil, noted by some ecologists ( $\mathrm{E}$
2/8). The locals referred to regeneration in terms of high seed variety, high germination, and good regeneration. These forests were said to be associated with relatively fertile, though not especially deep, soils.

All participants regarded the $\mathrm{N}$ state as extant. They considered small-scale and low-intensity extractive uses as compatible with the state, for example, harvesting of timber for house construction and farm enclosures (E 8/8; L 6/6) and extraction of nontimber products (e.g., honey; E 8/8; L 2/6). In some cases, goat herding was also considered compatible with the $\mathrm{N}$ state (E 5/8), and one local suggested that goats are important seed dispersers of some tree species.

\section{Seminatural state}

All the ecologists and locals described a seminatural forest state with markedly lower tree density and plant species richness than the $\mathrm{N}$ state, particularly in the tree layer. Tree height in this state is lower than in the $\mathrm{N}$ state, largely through the absence of 
emergent trees (Fig. 2). Some locals (L 3/6) coincided with ecologists, who noted an increased relative abundance of shrubs and herbs. A key difference between $\mathrm{N}$ and $\mathrm{sN}$ according to most of the ecologists and locals is the reduced abundance of natural regeneration (E 6/8; L 5/6); forest gaps remain open rather than regenerating (E 6/8). This pattern was explained as the result of high mortality of seeds and seedlings, which are more exposed to desiccation and herbivory in open areas. Additionally, one local mentioned a disease called "fever", which can kill adult trees.

\section{Transitions}

According to the locals, selective logging is the driver of $\mathrm{N} \rightarrow \mathrm{sN}$ transitions (L 5/6), triggered by selective logging intensity removing 2-5 stems/ha. The locals used phrases such as "logging leaves the forest more open". Although the ecologists agreed that selective logging reduces tree density, they reasoned that goat browsing changes the forest state by limiting tree regeneration and facilitating the establishment of fast-growing, thorny shrub species that are unpalatable for livestock (i.e., Croton spp.; E 8/8). When extensive livestock and logging combine, they can trigger the transition from $\mathrm{N} \rightarrow \mathrm{sN}$ over 5-20 years (Fig. 3).

For ecologists, livestock exclusion was the main restoration action required for changing from $\mathrm{sN} \rightarrow \mathrm{N}$, either over large areas ( $\mathrm{E}$ 7/8) or smaller cells (e.g., 100-900 $\mathrm{m}^{2}$; E 1/8), where exclusion is alternated to allow periodic access following regeneration. For some ecologists, this action was considered enough to allow forest recovery (E 3/8), whereas others combined exclusion with supplementary planting (E 1/8; L 2/6), logging control (E 1/8), or watering $(\mathrm{L} 1 / 6)$ to stimulate regeneration. Interestingly, although locals did not consider livestock an agent of $\mathrm{N} \rightarrow \mathrm{sN}$ transition, the majority ( $\mathrm{L} 4 / 6$ ) coincided with ecologists that excluding livestock was a key management strategy for $\mathrm{sN} \rightarrow \mathrm{N}$ transition (Fig. 3). Both groups were consistent in suggesting that the transition could occur between 3 and 30 years.

\section{Shrub-dominated state}

There was consensus between the ecologists and locals that the $\mathrm{Sd}$ state corresponds to a reduction in species richness and tree density, structural simplification of the tree layer, and changing dominance to shrubby and herbaceous strata (Fig. 2). Ecologists suggested that adult trees could be sparse or isolated in this state. Dense-wooded trees that can resist the browsing of livestock are the dominant species (e.g., Handroanthus chrysanthus and Caesalpinia glabrata; E 7/8). For the ecologists (E 6/8), there may or may not be large old trees in this state, and the distributions of seedling and juvenile plants tend to be restricted to below established trees. The increasing ground dominance by low shrubs was cited as an important characteristic of this state (E 7/8).

\section{Transitions}

Ecologists suggested that the transition from $\mathrm{sN} \rightarrow \mathrm{Sd}$ results from an increase in the livestock herd or continuation of annual goat herding and logging for a further 5-30 years, whereas locals mentioned an intensification of logging (Fig. 3). One local mentioned that there are no human factors related to this transition, but only natural factors such as pests and drought. Ecologists estimated different time ranges for this transition, from 5 to 30 years, whereas for locals, the time for this transition is between 2 and 20 years when the driver is logging (Appendix 3).
Fig. 3. State-transition model for the Zapotillo dry forest ecological site with the five forest states identified. Solid arrows represent transition possibilities (T1, T2, T3, T4); broken arrows represent chances of recovery (R1, R2, R3, R4, R5). Drivers of each transition, as well as management actions to reverse the disturbance process, are differentiated for ecologists' (E) and locals' (L) opinions and ordered by the frequency with which they were mentioned.

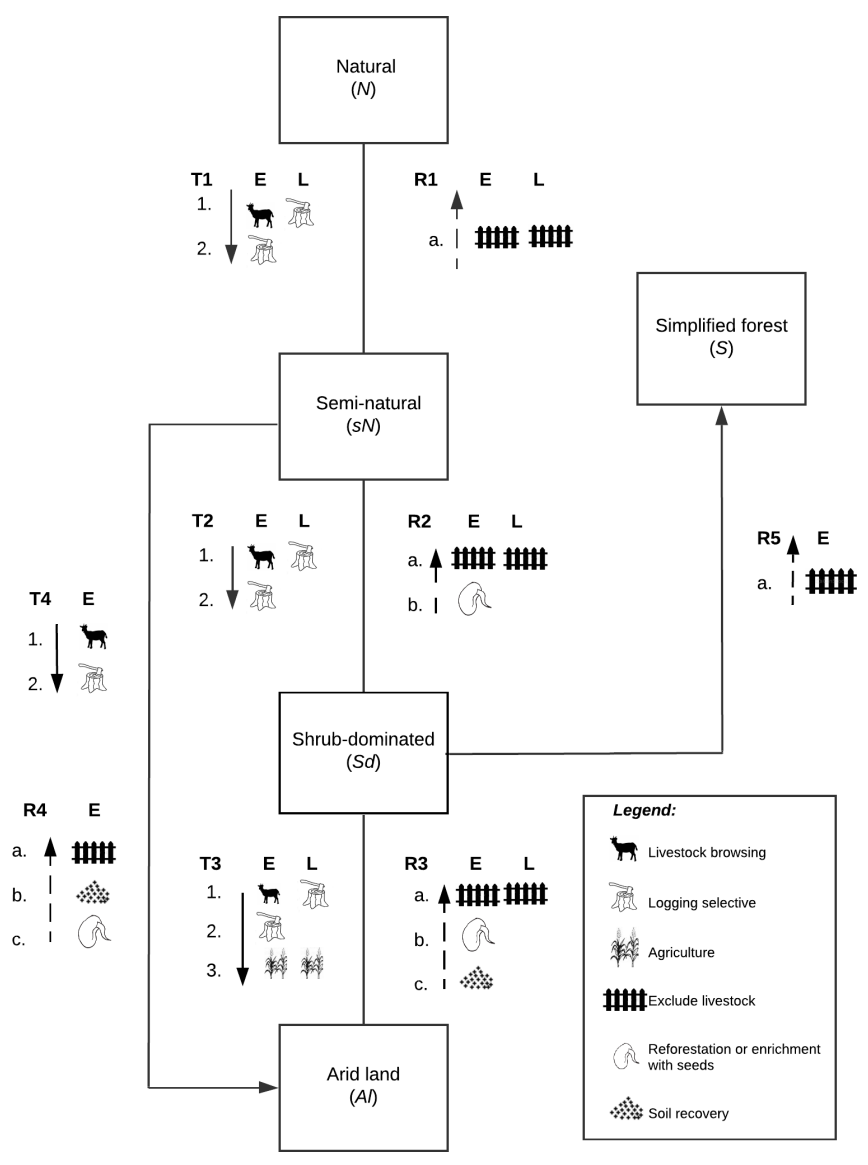

Livestock exclusion was considered the main action required to facilitate a return from $\mathrm{Sd} \rightarrow \mathrm{sN}(\mathrm{E} 7 / 8 ; \mathrm{L} 5 / 6)$. Ecologists and locals highlighted the need to combine it with active soil recovery practices and the planting or seeding of trees (L 3/6) or other woody species that provide missing habitat resources for wildlife or facilitate the regeneration of other plant species (E 3/3). Perceptions about the length of time it might take to return $\mathrm{Sd}$ $\rightarrow \mathrm{sN}$ varied from $<10$ years $(\mathrm{E} 1 / 8 ; \mathrm{L} 2 / 6)$ to $20-30$ years $(\mathrm{E} 1 / 8)$ or $>50$ years $(\mathrm{E} 1 / 8 ; \mathrm{L} 3 / 6)$.

\section{Simplified state}

Areas that are dominated by a particular species are widely recognized by people in the Zapotillo area (e.g., Palo Santo Valley and Guayacanes Forest). However, only a subset of interviewees recognized those areas as a distinct ecosystem state. In the second round of interviews, only three ecologists (E 3/8) postulated that applying livestock exclusion alone to areas in the $\mathrm{Sd}$ state can result in the transition $\mathrm{Sd} \rightarrow \mathrm{S}$ (Figs. 2 and 3). Removal of livestock 
browsing from such sites was considered to advantage those remaining species with resprouting capacity (e.g., Handroanthus spp.). Thus, the $\mathrm{S}$ state is characterized by a low level of species evenness compared with $\mathrm{N}$ and $\mathrm{sN}$.

\section{Arid land state}

Ecologists and locals all described a state with very low plant species richness and tree density compared to N (Fig. 2). The key characteristic of this state is the dominance of ground cover by the low shrub Ipomoea carnea (Appendix 3), which can exceed $70 \%$ of the vegetative cover. For example, locals mentioned phrases such as "the more open the forest is, the more herbs there are", "borrachera (I. carnea) is the most abundant species", "it is everywhere". Ecologists added that under this species, no regeneration of any species is observed. What trees remain are very isolated. There was consensus that the soil is conspicuously bare and eroded. Locals said phrases such as "the ground is broken, it slips when it rains because it is without vegetation", "it is worn and hard", or "compacted".

\section{Transitions}

According to the ecologists, a transition from $\mathrm{Sd} \rightarrow \mathrm{Al}$ occurs when the traditional system of raising goats is maintained. Ecologists indicated that this transition could take from $<3$ years to 10 years (Appendix 3). Five ecologists mentioned that a direct transition from $\mathrm{sN} \rightarrow \mathrm{Al}$ can be triggered by the intensification of livestock herding and logging in an sN state (Fig. 3).

Ecologists agreed that once the Al state is reached, restoration is difficult, if not effectively irreversible (E 2/8). To return from Al $\rightarrow \mathrm{Sd}$, ecologists proposed the combination of livestock exclusion followed by soil recovery and reforestation (Fig. 3). Additionally, the locals and ecologists mentioned that in this state, it is necessary to improve the source of plant regeneration. For example, locals mentioned that "trees should be planted". Ecologists mentioned two strategies: (1) enrichment with seeds from various woody species, and (2) reforestation with nurse or engineer plants that improve the soil and generate suitable conditions for other species. The success of these actions will depend, in part, on the distance from other forests that can be a source of seeds and wildlife visits (E 1/8). According to locals, livestock exclusion followed by planting shrubs can facilitate a shrubby stratum recovery in one year. However, recovery of tree stratum is difficult, and can take $>50$ years. Trees of Caesalpinia glabrata and Prosopis juliflora would grow on bare soil if manually watered (L 1/6).

Ecologists suggested that managing areas from $\mathrm{Al} \rightarrow \mathrm{sN}$ using the above strategies might take $50-100$ years (E 2/8) or $>100$ years (E 1/8). Others (E 2/8) regarded this transition as effectively impossible (Appendix 3).

There were divergent ideas about the risk phase for transitions from one state to another. Some ecologists and all locals (E 3/8; L 6/6) mentioned the dry season as the risk phase because of the intensification of selective logging, goat ranching, and burning. Locals also attributed the vulnerability to extreme drought events, which cause the death of trees and low regeneration. Two other ecologists indicated the cusp between rainy and dry seasons as the risk phase because many plants disperse their seeds and germinate during or at the end of the rainy season so that browsing livestock during that period causes high seedling mortality. For three other ecologists, the risk phase is the beginning of the rainy season because local people may burn areas of forest with the intent to sow crops (Appendix 3). This practice effectively signals a transition to a nonforest, cultivated state. However, because none of the interviewees provided further information about the characteristics and stability of the cultivation state or transitions back out of cultivation into secondary forest, we have not recognized the state in our model.

\section{DISCUSSION}

We developed a STM for SDTF in Zapotillo County comprising five distinguishable states. Both locals and ecologists coincided on four of those states, and these agreements allowed us to define a STM where transitions are characterized by progressive loss of tree density and species richness in all strata as the time and intensity of forest use increases. Some ecologists suggested an additional simplified forest state that may result from the limited regeneration of forest structure from the $\mathrm{Sd}$ state.

Although locals and ecologists agreed on the existence and characteristics of most states, they rarely coincided in identifying the main drivers of transitions between states. Locals attributed transitions to more open and simplified states to logging. Although the ecologists also recognized that driver, they considered overbrowsing by goats as the most important driver. Both drivers plausibly affect tree density in the forest, but whereas logging modifies density by removing established trees, overgrazing affects density by inhibiting the recruitment of tree saplings. The locals proposed that drought could intensify the loss of trees, emphasizing that climate changes may accentuate that process. This debate reprises another from the Peruvian side of the border (Perevolotsky 1991), where irreversible loss of vegetation and soil in dry forest were attributed by ecologists to overgrazing by goats, whereas those involved in goat-herding felt that extreme drought was the root cause.

Indeed, the logging and browsing stressors are not mutually exclusive. The loss of trees via natural death or logging and the reduction of recruitment capacity are additive stressors, and prolonged exposure and moderate intensity can move the forest from $\mathrm{N}$ to Al states. Currently, there are no local empirical data detailing the spatial extent and intensity of logging, tree mortality, and browsing; nor is there information about the thresholds that would help to identify management regimes consistent with maintaining forest in $\mathrm{N}$ or $\mathrm{sN}$ states. It is necessary to design studies that test the importance of each of the drivers in the transitions toward less conserved forest states. However, part of the lesson of our study is the opportunity to focus not on the causes of degradation, but also in management actions that may cause desirable changes from this point onward. Also, a focus on what types of management should happen next may involve taking a step back from the forests to consider management in its land use context.

Transitions from forest to cultivation and the sowing of cash crops were mentioned by some interviewees but remained beyond the scope of our model. These transitions were said to proceed via the deliberate burning of forested areas to facilitate clearing. Interviewees tended to conceive of them as a terminal transition to a nonforest state because those areas tend to be maintained in cultivation indefinitely. Conversion of dry forest to farmland is increasing in the study region. Since the 1970 s, approximately $9 \%$ of SDTF land in southern Ecuador has been converted to crops 
(Tapia-Armijos et al. 2015), and even larger areas of dry forest were converted to pastoral use in parts of Mexico over the same period (Flores-Casas and Ortega-Huerta 2019). Although we confined the scope of our STM to consider ecological states within extant forest, we make two observations. First, forest recovery following agricultural abandonment is commonplace elsewhere, including in some relatively analogous ecosystem types (e.g., Burgos and Maass 2004). Therefore, although reversion to forest from cultivation is not observed in the study area, it is a plausible future scenario. Second, there is no technical barrier to representing transitions to novel or as yet undocumented states within the STM framework (Bestelmeyer et al. 2015). For the case study region, we suggest that the prevalence of SDTF $\rightarrow$ cultivation transitions could be advanced via spatial analyses, and then the STM can be updated to include nonforest states and the likely net change in area of forest and nonforest states.

Clearly, management actions to promote forest recovery should respond to the forest degradation state and the desired outcome (e.g., Chazdon 2008), but such nuance is rarely evident in management programs (Suárez et al. 2012). Our STM suggested that even at spatial scales of a few kilometers, it is necessary to apply different restoration actions depending on the current state of the forest. Whereas livestock exclusion can be a sufficient practice to reverse the disturbance process in the $\mathrm{sN}$ state because of the good regeneration capacity that is maintained, the more severe and prolonged degradation that affects the soil function in Al will probably require more active restoration (King and Hobbs 2006, Chazdon 2008). In this context, the consensus among ecologist and locals regarding changes in soil conditions is important because it suggests a shared awareness that may facilitate the application of soil recovery actions, which are highlighted elsewhere as critical in dry forest function (Balvanera et al. 2002, Maestre et al. 2012, Ayala-Orozco et al. 2018). Additionally, because most participants agreed that the reference state supports human activities, including livestock grazing, management actions with a land-sharing approach can be applied in this area (Lusiana et al. 2012). Considering the perception of some locals that the forest provides a critical shelter and forage resource for goats, and the suggestion that goats provide an ecosystem service to the forest as seed dispersers, the reduction of livestock load, instead of eradication, may be the most viable management pathway to explore. Some private conservation initiatives in the study area (e.g., La Ceiba Reserve) allow associations of local people to use the forest for free-range herding of goats. Additionally, a recent analysis of land and forest use in the region posited that allowing extensive goat herding within the forest ecosystem was an important factor in reducing the conversion rate of forest to agriculture (Ochoa et al. 2016). However, the characteristics of a regime of goat herding that is consistent with maintenance of $\mathrm{N}$ state forest over the middle to long term are unknown, and research to fill this knowledge gap should be a priority.

The use of a STM allowed us to identify an alternative, S state that results when livestock exclusion is applied as the only restoration action in Sd forest. Although ecologists mentioned that this state might represent a stable forest state, the dynamics of the state are largely unknown. The ecologists emphasized that the tree species that dominate the $\mathrm{Sd}$ and $\mathrm{Al}$ states have dense wood and resprouting ability, which suggests that environmental filtering may explain the loss of species diversity in those states (e.g., López-Martínez et al. 2013). Because the S state is derived from exclusion of browsing on Sd management, the dominant species of S must arise from the filtered set in Sd. An example of $\mathrm{S}$ is those areas dominated by Handroanthus chrysanthus, with very few other tree species. Because the $\mathrm{S}$ state was recognized by a subgroup of ecologists at the end of the second round of interviews, its characteristics and drivers of transition could not be contrasted with the locals, so it is necessary to gather more information on the perception of locals regarding this state.

In common with many STM models, the states proposed as stable, semidiscrete entities are informed caricatures, and the transitions between them are even more so. These models are not a substitute for more empirical approaches to monitoring and managing ecosystem condition and function. However, STM structures have been shown to be compatible with quantitative learning and adaptive management approaches (e.g., Gillet et al. 2002, Rumpff et al. 2011, Chee et al. 2016). More than 30 years ago in their global overview of the ecology of dry forest systems, Murphy and Lugo (1986) called for long-term data from representative forest sites to be collected to understand the dynamics and implications of different management regimes. Unfortunately, that need remains as great as ever. For the SDTF of Zapotillo, long-term data or empirical insights are required to verify the states and the dynamic behavior and transitions that our experts proposed. These propositions can be best understood as hypotheses or models that can be tested empirically in an adaptive learning framework (Duncan and Wintle 2008). The STM can play a valuable role in suggesting priority knowledge gaps that apply not only to the ecological dynamics but also to the social-ecological dynamics of the forest as a vital resource that sustains livelihoods, ecosystem services, and globally significant biodiversity.

Additional model development is required for this model to help facilitate subsequent phases of forest management and restoration. Our model elicitation did not explicitly test the relative desirability of the states for the different groups of participants. One might presume that the preference of the ecologists would be to maximize the amount of SDTF area in the $\mathrm{N}$ state, but further work should illuminate the value judgements and preferences of the local experts. Further work could also include other stakeholder groups. For example, nascent nondestructive uses of the SDTF are extraction of essential oils from Bursera graveolens (Palo Santo), and tourism associated with mass flowering of Handroanthus chrysanthus (Guayacán). Promoters of these activities may have an important stake in the forest states that may be most desirable as well as opinions and experience about what drivers control the state and what management may be beneficial or adverse.

The STM described here reflects a direct relationship between people and forest, based mainly on the use of forest as a service for the provision of subsistence resources. The SDTF of Zapotillo share many socio-environmental characteristics with other SDTF of the Neotropics, such as Machalilla National Park in northwestern Ecuador (Lizcano et al. 2016; E. De la Montaña and V. Pares, personal communication, 2 February 2018) or Tehuacán-Cuicatlán Biosphere Reserve in Mexico (Baraza Ruiz and Estrella-Ruiz 2008). In those areas, people use the forest for livestock raising (mainly goats), impeding forest recovery. In the 
particular case of the SDTF of Machalilla, similar patterns of tree density loss and reduced forest species regeneration have been observed as livestock load increases (E. De la Montaña and V. Pares, personal communication, 2 February 2018).

\section{CONCLUSION}

The model described here resulted from the participation of local experts and ecologists and provides a sound basis for further development of the model itself and strategies for sustainable use and conservation of the SDTF in Zapotillo County. The use of multiple knowledge sources affords the model credibility. Future model development should continue to invite the participation of these and other stakeholder groups so that the resulting strategies have the greatest chance of acceptance and implementation.

Although the model provides important local information and perspectives on the dynamics of SDTF, it is clear that many critical knowledge gaps remain that must be addressed to facilitate evidence-based management of the SDTF ecosystem. The opinions regarding the duration, intensity, and scale of management regimes that may provoke undesirable and irreversible state changes or favorable restoration outcomes were uncertain for both ecologists and locals. Perhaps more importantly, discussions about the overall objectives, i.e., the relative amount of area of each state desired by the local and broader stakeholder communities, must be resolved for model representations of ecosystem management to have greatest effect in a management-planning context.

\section{Responses to this article can be read online at:} http://www.ecologyandsociety.org/issues/responses. php/11142

\section{Acknowledgments:}

We are grateful to the ecologists and locals who contributed with information to this work and to those who care about the conservation of the seasonally dry tropical forests of Zapotillo. We thank Diego Armijos who collaborated with the fieldwork, Verónica Iñiguez for methodological advice, and Daniel Griffith who, together with his colleagues (E. De la Montaña, V. Pares, and L. Cervera), provided us with information about other dry forests of Ecuador. Thanks to Daniel Rosado for his ideas to improve the first version of this work.

\section{LITERATURE CITED}

Agrawal, A. 1995. Dismantling the divide between indigenous and scientific knowledge. Development and Change 26(3):413-439. https://doi.org/10.1111/j.1467-7660.1995.tb00560.x

Aguirre Mendoza, Z., and G. Geada-Lopez. 2017. Conservation status of the dry forests of the province of Loja, Ecuador / Estado de conservación de los bosques secos de la provincia de Loja, Ecuador. Arnaldoa 24(1):207-228. http://dx.doi.org/10.22497/ arnaldoa.241.24107

Aguirre Mendoza, Z., and L. P. Kvist. 2005. Floristic composition and conservation status of the dry forests in Ecuador / Compisición florística y estado de conservación de los bosques secos del sur-occidente del Ecuador. Lyonia 8(2):41-67. [online] URL: https://www.lyonia.org/viewarticle-414

Avirmed, O., M. D. White, K. Batpurev, P. Griffioen, C. Liu, S. Jambal, H. Sime, K. Olson, and S. J. Sinclair. 2018. Rangeland condition metrics for the Gobi Desert, derived from stakeholder evaluations. Arthur Rylah Institute for Environmental Research Technical Report Series 289. State of Victoria Department of Environment, Land, Water and Planning, Heidelberg, Australia. [online] URL: https://www.ari.vic.gov.au/ data/assets/ pdf file/0025/213649/ARI-Technical-Report-289-Rangeland-conditionmetrics-for-the-Gobi-Desert.pdf

Ayala-Orozco, B., M. E. Gavito, F. Mora, I. Siddique, P. Balvanera, V. J. Jaramillo, H. Cotler, L. P. Romero-Duque, and E. Martínez-Meyer. 2018. Resilience of soil properties to landuse change in a tropical dry forest ecosystem. Land Degradation and Development 29(2):315-325. https://doi.org/10.1002/ldr.2686

Balvanera, P., E. Lott, G. Segura, C. Siebe, and A. Islas. 2002. Patterns of $\beta$-diversity in a Mexican tropical dry forest. Journal of Vegetation Science 13(2):145-158. https://doi.org/10.1111/ j.1654-1103.2002.tb02034.x

Baraza Ruiz, E., and J. P. Estrella-Ruiz. 2008. Manejo sustentable de los recursos naturales guiado por proyectos científicos en la mixteca poblana mexicana. Ecosistemas 17(2):3-9. [online] URL: https://www.revistaecosistemas.net/index.php/ecosistemas/article/ view/98

Bélisle, A. C., H. Asselin, P. LeBlanc, and S. Gauthier. 2018. Local knowledge in ecological modeling. Ecology and Society 23(2):14. https://doi.org/10.5751/ES-09949-230214

Bennett, E. M., W. Cramer, A. Begossi, G. Cundill, S. Díaz, B. N. Egoh, I. R. Geijzendorffer, C. B. Krug, S. Lavorel, E. Lazos, L. Lebel, B. Martín-López, P. Meyfroidt, H. A. Mooney, J. L. Nel, U. Pascual, K. Payet, N. P. Harguindeguy, G. D. Peterson, A.-H. Prieur-Richard, B. Reyers, P. Roebeling, R. Seppelt, M. Solan, P. Tschakert, T. Tscharntke, B. L. Turner II, P. H. Verburg, E. F. Viglizzo, P. C. L. White, and G. Woodward. 2015. Linking biodiversity, ecosystem services, and human well-being: three challenges for designing research for sustainability. Current Opinion in Environmental Sustainability 14:76-85. https://doi. org/10.1016/j.cosust.2015.03.007

Bestelmeyer, B. T., A. Ash, J. R. Brown, B. Densambuu, M. Fernández-Giménez, J. Johanson, M. Levi, D. Lopez, R. Peinetti, L. Rumpff, and P. Shaver. 2017. State and transition models: theory, applications, and challenges. Pages 303-345 in D. D. Briske, editor. Rangeland systems: processes, management and challenges. Springer, Cham, Switzerland. https://doi. org/10.1007/978-3-319-46709-2 9

Bestelmeyer, B. T., K. Moseley, P. Shaver, H. Sanchez, D. Briske, and M. Fernandez-Gimenez. 2010. Practical advice for developing state-and-transition models. Rangelands 32(6):23-30. https://doi.org/10.2111/RANGELANDS-D-10-00077.1

Bestelmeyer, B. T., G. S. Okin, M. C. Duniway, S. R. Archer, N. F. Sayre, J. C. Williamson, and J. E. Herrick. 2015. Desertification, land use, and the transformation of global drylands. Frontiers in Ecology and the Environment 13(1):28-36. https://doi. org/10.1890/140162 
Bland, L. M., D. A. Keith, R. M. Miller, N. J. Murray, and J. P. Rodríguez. 2016. Directrices para la aplicación de las categorías y criterios de la Lista Roja de Ecosistemas de UICN. International Union for the Conservation of Nature, Gland, Switzerland. [online] URL: https://www.iucn.org/es/content/directrices-parala-aplicaci $\% \mathrm{C} 3 \% \mathrm{~B} 3 n$-de-las-categor $\% \mathrm{C} 3 \% \mathrm{AD}$ as-y-criterios-de-la$\underline{\text { lista-roja-de-ecosistemas-de-uicn }}$

Burgos, A., and J. M. Maass. 2004. Vegetation change associated with land-use in tropical dry forest areas of western Mexico. Agriculture, Ecosystems and Environment 104(3):475-481. https:// doi.org/10.1016/j.agee.2004.01.038

Cabrera, O., Z. Aguirre, W. Quizhpe, and R. Alvarado. 2002. Estado actual y perspectivas de conservación de los bosques secos del suroccidente ecuatoriano. Pages 65-78 in Z. Aguirre, J. E. Madsen, E. Cotton, and H. Balslev, editors. Botánica Austroecuatoriana: estudios sobre los recursos vegetales en las provincias de El Oro, Loja y Zamora Chinchipe. Abya Yala, Quito, Ecuador.

Cash, D. W., W. C. Clark, F. Alcock, N. M. Dickson, N. Eckley, D. H. Guston, J. Jäger, and R. B. Mitchell. 2003. Knowledge systems for sustainable development. Proceedings of the National Academy of Sciences 100(14):8086-8091. https://doi.org/10.1073/ pnas. 1231332100

Chazdon, R. L. 2008. Beyond deforestation: restoring forests and ecosystem services on degraded lands. Science 320:1458-1460. https://doi.org/10.1126/science.1155365

Chee, Y. E., L. Wilkinson, A. E. Nicholson, P. F. QuintanaAscencio, J. E. Fauth, D. Hall, K. J. Ponzio, and L. Rumpff. 2016. Modelling spatial and temporal changes with GIS and spatial and dynamic Bayesian networks. Environmental Modelling and Software 82:108-120. https://doi.org/10.1016/j.envsoft.2016.04.012

Cook, C. N., M. Hockings, and R. W. Carter. 2010. Conservation in the dark? The information used to support management decisions. Frontiers in Ecology and the Environment 8(4):181-188. https://doi.org/10.1890/090020

Cooke, R. M. 1991. Experts in uncertainty: opinion and subjective probability in science. Oxford University Press, Oxford, UK.

Cueva Ortiz, J., and L. A. Chalán. 2010. Cobertura vegetal y uso actual del suelo de la provincia de Loja. Technical Report. Naturaleza y Cultura Internacional, Piura, Peru.

Cueva Ortiz, J., C. I. Espinosa, C. Quiroz Dahik, Z. Aguirre Mendoza, E. Cueva Ortiz, E. Gusmán, M. Weber, and P. Hildebrandt. 2019. Influence of anthropogenic factors on the diversity and structure of a dry forest in the central part of the Tumbesian Region (Ecuador-Perú). Forests 10(1):31. https://doi. org/10.3390/f10010031

Davis, S. D., V. H. Heywood, and A. C. Hamilton, editors. 1997. Centres of plant diversity: a guide and strategy for their conservation, volume 3: the Americas. World Wide Fund for Nature and World Conservation Union, Cambridge, UK.

de la Cruz, M., P. F. Quintana-Ascencio, L. Cayuela, C. I. Espinosa, and A. Escudero. 2017. Comment on "The extent of forest in dryland biomes". Science 358(6362):eaao0166. https:// doi.org/10.1126/science.aao0369
DeFries, R., and H. Nagendra. 2017. Ecosystem management as a wicked problem. Science 356(6335): 265-270. https://doi. org/10.1126/science.aal1950

Dinerstein, E., D. M. Olson, D. J. Graham, A. L. Webster, S. A. Primm, M. P. Bookbinder, and G. Ledec. 1995. A conservation assessment of the terrestrial ecoregions of Latin America and the Caribbean. World Bank, Washington, D.C., USA. https://doi. org/10.1596/0-8213-3295-3

Duncan, D. H., G. Kyle, and D. Race. 2010. Combining facilitated dialogue and spatial data analysis to compile landscape history. Environmental Conservation 37(4):432-441. https://doi.org/10.1017/ $\underline{\mathrm{S} 0376892910000767}$

Duncan, D. H., and B. A. Wintle. 2008. Towards adaptive management of native vegetation in regional landscapes. Pages 159-182 in C. Pettit, W. Cartwright, I. Bishop, K. Lowell, D. Pullar, and D. Duncan, editors. Landscape analysis and visualisation: spatial models for natural resource management and planning. Springer, Berlin, Germany. https://doi.org/10.1007/978-3-540-69168-6_9

Eastburn, D. J., A. T. O'Geen, K. W. Tate, and L. M. Roche. 2017. Multiple ecosystem services in a working landscape. Plos One 12 (3):e0166595. https://doi.org/10.1371/journal.pone.0166595

Escribano-Avila, G., L. Cervera, L. Ordóñez-Delgado, A. JaraGuerrero, L. Amador, B. Paladines, J. Briceño, V. Parés-Jiménez, D. J. Lizcano, D. H. Duncan, and C. I. Espinosa. 2017. Biodiversity patterns and ecological processes in Neotropical dry forest: the need to connect research and management for longterm conservation. Neotropical Biodiversity 3(1):107-116. https:// doi.org/10.1080/23766808.2017.1298495

Espinosa, C. I., O. Cabrera, A. L. Luzuriaga, and A. Escudero. 2011. What factors affect diversity and species composition of endangered Tumbesian dry forests in southern Ecuador? Biotropica 43(1):15-22. https://doi.org/10.1111/j.1744-7429.2010.00665. $\underline{\mathrm{x}}$

Espinosa, C. I., M. de la Cruz, A. Jara-Guerrero, E. Gusmán, and A. Escudero. 2016. The effects of individual tree species on species diversity in a tropical dry forest change throughout ontogeny. Ecography 39(3):329-337. https://doi.org/10.1111/ecog.01328

Espinosa, C. I., M. de la Cruz, A. L. Luzuriaga, and A. Escudero. 2012. Bosques tropicales secos de la región Pacífico Ecuatorial: diversidad, estructura, funcionamiento e implicaciones para la conservación. Ecosistemas 21(1-2):167-179. [online] URL: https://www.revistaecosistemas.net/index.php/ecosistemas/article/ view/35

Flores-Casas, R., and M. A. Ortega-Huerta. 2019. Modelling land cover changes in the tropical dry forest surrounding the Chamela-Cuixmala biosphere reserve, Mexico. International Journal of Remote Sensing 40(18):6948-6974. https://doi. org/10.1080/01431161.2019.1597305

Gillet, F., O. Besson, and J.-M. Gobat. 2002. PATUMOD: a compartment model of vegetation dynamics in wooded pastures. Ecological Modelling 147(3):267-290. https://doi.org/10.1016/ $\underline{\text { S0304-3800(01)00427-6 }}$

Granger Morgan, M., B. Fischhoff, A. Bostrom, and C. J. Atman. 2002. Risk communication: a mental models approach. Cambridge University Press, Cambridge, USA. 
Grechi, I., I. Chadès, Y. M. Buckley, M. H. Friedel, A. C. Grice, H. P. Possingham, R. D. van Klinken, and T. G. Martin. 2014. A decision framework for management of conflicting production and biodiversity goals for a commercially valuable invasive species. Agricultural Systems 125:1-11. https://doi.org/10.1016/j. agsy.2013.11.005

Harper, M., and P. Cole. 2012. Member checking: Can benefits be gained similar to group therapy? Qualitative Report 17 (2):510-517. [online] URL: https://nsuworks.nova.edu/tqr/vol17/ iss $2 / 1 /$

Hurtado, S. 2015. Actualización del plan de desarrollo y ordenamiento territorial del Cantón Zapotillo: actualización 20152019. Gobierno Autónomo Descentralizado del Cantón Zapotillo, Zapotillo, Ecuador.

Hobbs, R. J., L. M. Hallett, P. R. Ehrlich, and H. A. Mooney. 2011. Intervention ecology: applying ecological science in the twenty-first century. Bioscience 61(6):442-450. https://doi. org/10.1525/bio.2011.61.6.6

Instituto Nacional de Estadísticas y Censos (INEC). 2010. Resultados del censo 2010 de población y vivienda en el Ecuador: fascículo provincial Loja. INEC, Quito, Ecuador. [online] URL: https://www.ecuadorencifras.gob.ec/wp-content/descargas/Manulateral/Resultados-provinciales/loja.pdf

James, J. J., R. L. Sheley, T. Erickson, K. S. Rollins, M. H. Taylor, and K. W. Dixon. 2013. A systems approach to restoring degraded drylands. Journal of Applied Ecology 50(3):730-739. https://doi. org/10.1111/1365-2664.12090

Jara-Guerrero, A., M. de la Cruz, C. I. Espinosa, M. Méndez, and A. Escudero. 2015. Does spatial heterogeneity blur the signature of dispersal syndromes on spatial patterns of woody species? A test in a tropical dry forest. Oikos 124(10):1360-1366. https://doi.org/10.1111/oik.02098

Jara-Guerrero, A., M. de la Cruz, and M. Méndez. 2011. Seed dispersal spectrum of woody species in south Ecuadorian dry forests: environmental correlates and the effect of considering species abundance. Biotropica 43(6):722-730. https://doi. org/10.1111/j.1744-7429.2011.00754.X

Jara-Guerrero, A., G. Escribano-Avila, C. I. Espinosa, M. De la Cruz, and M. Méndez. 2018. White-tailed deer as the last megafauna dispersing seeds in Neotropical dry forests: the role of fruit and seed traits. Biotropica 50(1):169-177. https://doi. org/10.1111/btp. 12507

Johnson, C. J., C. A. Drew, and A. H. Perera. 2012. Elicitation and use of expert knowledge in landscape ecological applications: a synthesis. Pages 279-299 in A. H. Perera, C. A. Drew, and C. J. Johnson, editors. Expert knowledge and its application in landscape ecology. Springer, New York, New York, USA. https://doi. org/10.1007/978-1-4614-1034-8 14

King, E. G., and R. J. Hobbs. 2006. Identifying linkages among conceptual models of ecosystem degradation and restoration: towards an integrative framework. Restoration Ecology 14 (3):369-378. https://doi.org/10.1111/j.1526-100X.2006.00145.x

Knapp, C. N., M. Fernandez-Gimenez, E. Kachergis, and A. Rudeen. 2011. Using participatory workshops to integrate state- and-transition models created with local knowledge and ecological data. Rangeland Ecology and Management 64 (2):158-170. https://doi.org/10.2111/REM-D-10-00047.1

Laycock, W. A. 1991. Stable states and thresholds of range condition on North American rangelands: a viewpoint. Journal of Range Management 44(5):427-433. https://doi.org/10.2307/4002738

Lizcano, D. J., L. Cervera, S. Espinoza-Moreira, D. PoaquizaAlava, V. Parés-Jiménez, and P. J. Ramírez-Barajas. 2016. Medium and large mammal richness from the marine and coastal wildlife refuge of Pacoche, Ecuador. Therya 7(1):135-145. https://doi. org/10.12933/therya-16-308

López-Martínez, J. O., L. Sanaphre-Villanueva, J. M. Dupuy, J. L. Hernández-Stefanoni, J. A. Meave, and J. A. Gallardo-Cruz. 2013. $\beta$-diversity of functional groups of woody plants in a tropical dry forest in Yucatan. Plos One 8(9):e73660. https://doi. org/10.1371/journal.pone.0073660

Lusiana, B., M. van Noordwijk, and G. Cadisch. 2012. Land sparing or sharing? Exploring livestock fodder options in combination with land use zoning and consequences for livelihoods and net carbon stocks using the FALLOW model. Agriculture, Ecosystems and Environment 159:145-160. https:// doi.org/10.1016/j.agee.2012.07.006

Lynam, T., F. Bousquet, C. Le Page, P. d'Aquino, O. Barreteau, F. Chinembiri, and B. Mombeshora. 2002. Adapting science to adaptive managers: spidergrams, belief models, and multi-agent systems modeling. Conservation Ecology 5(2):24. [online] URL: http://www.consecol.org/vol5/iss2/art24/

Maestre, F. T., J. L. Quero, N. J. Gotelli, A. Escudero, V. Ochoa, M. Delgado-Baquerizo, M. García-Gómez, M. A. Bowker, S. Soliveres, C. Escolar, P. García-Palacios, M. Berdugo, E. Valencia, B. Gozalo, A. Gallardo, L. Aguilera, T. Arredondo, J. Blones, B. Boeken, D. Bran, A. A. Conceição, O. Cabrera, M. Chaieb, M. Derak, D. J. Eldridge, C. I. Espinosa, A. Florentino, J. Gaitán, M. G. Gatica, W. Ghiloufi, S. Gómez-González, J. R. Gutiérrez, R. M. Hernández, X. Huang, E. Huber-Sannwald, M. Jankju, M. Miriti, J. Monerris, R. L. Mau, E. Morici, K. Naseri, A. Ospina, V. Polo, A. Prina, E. Pucheta, D. A. Ramírez-Collantes, R. Romão, M. Tighe, C. Torres-Díaz, J. Val, J. P. Veiga, D. Wang, and E. Zaady. 2012. Plant species richness and ecosystem multifunctionality in global drylands. Science 335(6065):214-218. https://doi.org/10.1126/science.1215442

Martin, T. G., M. A. Burgman, F. Fidler, P. M. Kuhnert, S. LowChoy, M. McBride, and K. Mengersen. 2012. Eliciting expert knowledge in conservation science. Conservation Biology 26 (1):29-38. https://doi.org/10.1111/j.1523-1739.2011.01806.X

McBride, M. F., S. T. Garnett, J. K. Szabo, A. H. Burbidge, S. H. M. Butchart, L. Christidis, G. Dutson, H. A. Ford, R. H. Loyn, D. M. Watson, and M. A. Burgman. 2012. Structured elicitation of expert judgments for threatened species assessment: a case study on a continental scale using email. Methods in Ecology and Evolution 3(5):906-920. https://doi.org/10.1111/j.2041-210X.2012.00221. $\underline{x}$

McIntyre, S., and S. Lavorel. 2007. A conceptual model of land use effects on the structure and function of herbaceous vegetation. Agriculture, Ecosystems and Environment 119(1-2):11-21. https:// doi.org/10.1016/j.agee.2006.06.013 
Mistry, J., and A. Berardi. 2016. Bridging indigenous and scientific knowledge. Science 352(6291):1274-1275. https://doi. org/10.1126/science.aaf1160

Murphy, P. G., and A. E. Lugo. 1986. Ecology of tropical dry forest. Annual Review of Ecology and Systematics 17:67-88. https://doi.org/10.1146/annurev.es.17.110186.000435

Myers, N., R. A. Mittermeier, C. G. Mittermeier, G. A. B. da Fonseca, and J. Kent. 2000. Biodiversity hotspots for conservation priorities. Nature 403(6772):853-858. https://doi.org/10.1038/35002501

Newing, H. 2011. Conducting research in conservation: social science methods and practice. Routledge, London, UK. https:// doi.org/10.4324/9780203846452

Ochoa, W. S., C. Paul, L. M. Castro, L. Valle, and T. Knoke. 2016. Banning goats could exacerbate deforestation of the Ecuadorian dry forest - How the effectiveness of conservation payments is influenced by productive use options. Erdkunde 70(1):49-67. https://doi.org/10.3112/erdkunde.2016.01.04

Oliva, G., D. Ferrante, P. Paredes, G. Humano, and A. Cesa. 2016. A conceptual model for changes in floristic diversity under grazing in semi-arid Patagonia using the state and transition framework. Journal of Arid Environments 127:120-127. https:// doi.org/10.1016/j.jaridenv.2015.10.018

Olson, D. M., and E. Dinerstein. 2002. The global 200: priority ecoregions for global conservation. Annals of the Missouri Botanical Garden 89(2):199-224. http://dx.doi.org/10.2307/3298564

Perevolotsky, A. 1991. Goats or scapegoats - the overgrazing controversy in Piura, Peru. Small Ruminant Research 6 (3):199-215. https://doi.org/10.1016/0921-4488(91)90156-K

Portillo-Quintero, C. A., and G. A. Sánchez-Azofeifa. 2010. Extent and conservation of tropical dry forests in the Americas. Biological Conservation 143(1):144-155. https://doi.org/10.1016/ j.biocon.2009.09.020

Prell, C., K. Hubacek, M. Reed, C. Quinn, N. Jin, J. Holden, T. Burt, M. Kirby, and J. Sendzimir. 2007. If you have a hammer everything looks like a nail: traditional versus participatory model building. Interdisciplinary Science Reviews 32(3):263-282. https:// doi.org/10.1179/030801807X211720

Radford, I. J., C. R. Dickman, A. N. Start, C. Palmer, K. Carnes, C. Everitt, R. Fairman, G. Graham, T. Partridge, and A. Thomson. 2014. Mammals of Australia's tropical savannas: a conceptual model of assemblage structure and regulatory factors in the Kimberley region. Plos One 9(3):e92341. https://doi. org/10.1371/journal.pone.0092341

Raymond, C. M., I. Fazey, M. S. Reed, L. C. Stringer, G. M. Robinson, and A. C. Evely. 2010. Integrating local and scientific knowledge for environmental management. Journal of Environmental Management 91(8):1766-1777. https://doi.org/10.1016/ j.jenvman.2010.03.023

Reid, R. S., D. Nkedianye, M. Y. Said, D. Kaelo, M. Neselle, O. Makui, L. Onetu, S. Kiruswa, N. O. Kamuaro, P. Kristjanson, J. Ogutu, S. B. BurnSilver, M. J. Goldman, R. B. Boone, K. A. Galvin, N. M. Dickson, and W. C. Clark. 2016. Evolution of models to support community and policy action with science: balancing pastoral livelihoods and wildlife conservation in savannas of East Africa. Proceedings of the National Academy of Sciences 113(17):4579-4584. https://doi.org/10.1073/pnas.0900313106

Reynolds, J. F., D. M. Stafford Smith, E. F. Lambin, B. L. Turner II, M. Mortimore, S. P. J. Batterbury, T. E. Downing, H. Dowlatabadi, R. J. Fernandez, J. E. Herrick, E. Huber-Sannwald, H. Jiang, R. Leemans, T. Lynam, F. T. Maestre, M. Ayarza, and B. Walker. 2007. Global desertification: building a science for dryland development. Science 316(5826):847-851. https://doi. org/10.1126/science.1131634

Rumpff, L., D. H. Duncan, P. A. Vesk, D. A. Keith, and B. A. Wintle. 2011. State-and-transition modelling for adaptive management of native woodlands. Biological Conservation 144 (4):1224-1236. https://doi.org/10.1016/j.biocon.2010.10.026

Schulz, C., M. Martín Brañas, C. Núñez Pérez, M. Del Aguila Villacorta, N. Laurie, I. T. Lawson, and K. H. Roucoux. 2019. Peatland and wetland ecosystems in Peruvian Amazonia: indigenous classifications and perspectives. Ecology and Society 24(2):12. https://doi.org/10.5751/ES-10886-240212

Slottje, P., J. J. van der Sluijs, and A. B. Knol. 2008. Expert elicitation: methodological suggestions for its use in environmental health impact assessments. RIVM Letter Report 630004001/2008. National Institute for Public Health and the Environment, Bilthoven, The Netherlands. [online] URL: https://www.rivm.nl/ bibliotheek/rapporten/630004001.pdf

Spooner, P. G., and K. G. Allcock. 2006. Using a state-andtransition approach to manage endangered Eucalyptus albens (white box) woodlands. Environmental Management 38 (5):771-783. https://doi.org/10.1007/s00267-005-0133-2

Starfield, A. M. 1997. A pragmatic approach to modeling for wildlife management. Journal of Wildlife Management 61 (2):261-270. https://doi.org/10.2307/3802581

Steele, C. M., B. T. Bestelmeyer, L. M. Burkett, P. L. Smith, and S. Yanoff. 2012. Spatially explicit representation of state-andtransition models. Rangeland Ecology and Management 65 (3):213-222. https://doi.org/10.2111/REM-D-11-00047.1

Suárez, A., G. Williams-Linera, C. Trejo, J. I. Valdez-Hernández, V. M. Cetina-Alcalá, and H. Vibrans. 2012. Local knowledge helps select species for forest restoration in a tropical dry forest of central Veracruz, Mexico. Agroforestry Systems 85(1):35-55. https://doi.org/10.1007/s10457-011-9437-9

Tapia-Armijos, M. F., J. Homeier, C. I. Espinosa, C. Leuschner, and M. de la Cruz. 2015. Deforestation and forest fragmentation in south Ecuador since the 1970s - losing a hotspot of biodiversity. Plos One 10(9):e0133701. https://doi.org/10.1371/journal. pone. 0133701

Tarrasón, D., F. Ravera, M. S. Reed, A. J. Dougill, and L. Gonzalez. 2016. Land degradation assessment through an ecosystem services lens: integrating knowledge and methods in pastoral semi-arid systems. Journal of Arid Environments 124:205-213. https://doi.org/10.1016/j.jaridenv.2015.08.002

van der Sluijs, J. P., P. H. M. Janssen, A. C. Petersen, P. Kloprogge, J. S. Risbey, W. Tuinstra, and J. R. Ravetz. 2004. RIVM/MNP guidance for uncertainty assessment and communication: tool catalogue for uncertainty assessment. Report NWS-E-2004-37. 
Utrecht University and National Institute for Public Health and the Environment (RIVM), Utrecht and Bilthoven, The Netherlands. [online] URL: http://www.nusap.net/downloads/ toolcatalogue.pdf

Westoby, M., B. Walker, and I. Noy-Meir. 1989. Opportunistic management for rangelands not at equilibrium. Journal of Range Management 42(4):266-274. https://doi.org/10.2307/3899492

Whalley, R. D. B. 1994. State and transition models for rangelands: 1. Successional theory and vegetation change. Tropical Grasslands 28:195-205. [online] URL: http://www. tropicalgrasslands.info/public/journals/4/Historic/Tropical\%20Grasslands \%20Journal\%20archive/Abstracts/Vol 28 1994/Abs 280494 pp195_205.html

Wilkinson, S. R., M. A. Naeth, and F. K. A. Schmiegelow. 2005. Tropical forest restoration within Galapagos National Park: application of a state-transition model. Ecology and Society 10 (1):28. https://doi.org/10.5751/ES-01371-100128

Young, D., H. L. Perotto-Baldivieso, T. Brewer, R. Homer, and S. A. Santos. 2014. Monitoring British upland ecosystems with the use of landscape structure as an indicator for state-andtransition models. Rangeland Ecology and Management 67 (4):380-388. https://doi.org/10.2111/REM-D-13-00170.1 


\section{Appendix 1.}

Table A1.1. Scientific articles about seasonally dry tropical forest of Southern Ecuador, published by the interviewed ecologists from 2005 to date

\begin{tabular}{|c|c|c|}
\hline Name of author & Topic & Year \\
\hline $\begin{array}{l}\text { Cueva Ortiz, J., Espinosa, C.I. } \\
\text { Quiroz Dahik, C. Aguirre Mendoza } \\
\text { Z., Cueva Ortiz E., Gusmán E., } \\
\text { Weber M., and Hildebrandt P. }\end{array}$ & $\begin{array}{l}\text { Influence of anthropogenic factors on } \\
\text { the diversity and structure of a dry } \\
\text { forest in the central part of the } \\
\text { Tumbesian Region (Ecuador-Perú). }\end{array}$ & 2019 \\
\hline $\begin{array}{l}\text { Jara-Guerrero A., Escribano-Avila } \\
\text { G., Espinosa C.I., De la Cruz M., } \\
\text { and Méndez M. }\end{array}$ & $\begin{array}{l}\text { White-tailed deer as the last megafauna } \\
\text { dispersing seeds in Neotropical dry } \\
\text { forests: the role of fruit and seed traits. }\end{array}$ & 2018 \\
\hline $\begin{array}{l}\text { Gusmán-M., E, de la Cruz, M., } \\
\text { Espinosa C. I, Escudero A. }\end{array}$ & $\begin{array}{l}\text { Focusing on individual species reveals } \\
\text { the specific nature of assembly } \\
\text { mechanisms in a tropical dry-forest }\end{array}$ & 2018 \\
\hline Aguirre Z., and Geada-Lopez G. & $\begin{array}{l}\text { Conservation status of the dry forests } \\
\text { of the province of Loja, Ecuador. }\end{array}$ & 2017 \\
\hline $\begin{array}{l}\text { Escribano-Avila G., Cervera L., } \\
\text { Ordóñez-Delgado L., Jara-Guerrero } \\
\text { A., Amador L., Paladines B., } \\
\text { Briceño J., Parés-Jiménez V., } \\
\text { Lizcano D., Duncan D. and } \\
\text { Espinosa C.I. }\end{array}$ & $\begin{array}{l}\text { Biodiversity patterns and ecological } \\
\text { processes in Neotropical dry forest: the } \\
\text { need to connect research and } \\
\text { management for long-term } \\
\text { conservation. }\end{array}$ & 2017 \\
\hline $\begin{array}{l}\text { Espinosa C.I., Jara-Guerrero A., } \\
\text { Cisneros R., Sotomayor J., and } \\
\text { Escribano-Ávila G. }\end{array}$ & $\begin{array}{l}\text { Reserva Ecológica Arenillas ¿un } \\
\text { refugio de diversidad biológica o una } \\
\text { isla en extinción? }\end{array}$ & 2016 \\
\hline $\begin{array}{l}\text { Ordóñez-Delgado L., Tomás G., } \\
\text { Armijos-Ojeda D., Jara-Guerrero } \\
\text { A., Cisneros R., Espinosa C.I. }\end{array}$ & $\begin{array}{l}\text { Nuevos aportes al conocimiento de } \\
\text { avifauna en la región tumbesina; } \\
\text { implicaciones para la conservación de } \\
\text { la Reserva de Biosfera del Bosque } \\
\text { Seco, Zapotillo, Ecuador. }\end{array}$ & 2016 \\
\hline $\begin{array}{l}\text { Jara-Guerrero A., De la Cruz M., } \\
\text { Espinosa C.I., Méndez M. and } \\
\text { Escudero A. }\end{array}$ & $\begin{array}{l}\text { Does spatial heterogeneity blur the } \\
\text { signature of dispersal syndromes on } \\
\text { spatial patterns of woody species? A } \\
\text { test in a tropical dry forest. }\end{array}$ & 2015 \\
\hline
\end{tabular}


Espinosa C. I., de la Cruz M., JaraGuerrero A., Gusmán E. and Escudero A.

Aguirre Z., Betancourt Y., Geada López, G and González J.

Espinosa C.I., de la Cruz M., Luzuriaga A. L., Escudero A.

Jara-Guerrero A., De la Cruz M. and Méndez M.

Espinosa C.I., Cabrera O., Luzuriaga A., and Escudero A.

Cabrera, O., Z. Aguirre, W. Quizhpe and R. Alvarado.

Aguirre Z., and Kvist L.P.
The effects of individual tree species

2015 on species diversity in a tropical dry forest change throughout ontogeny

Floristic composition and structure of dry forests and their management for the development of the province of Loja, Ecuador.

Bosques tropicales secos de la región

Pacífico Ecuatorial : diversidad, estructura.

Seed dispersal spectrum of woody species in South Ecuadorian dry forests: environmental correlates and the effect of considering species abundance.

What factors affect diversity and 2011 species composition of endangered tumbesian dry forests in southern Ecuador?

Estado actual y perspectivas de 2002 conservación de los bosques secos del suroccidente ecuatoriano. Pp. 65-78. In Aguirre, Z. Madsen J.E., Cotton E. \& Balslev H. (eds.). Botánica Austroecuatoriana. Estudios sobre los recursos vegetales en las provincias de El Oro, Loja y Zamora Chinchipe. Floristic composition and conservation status of the dry forests in Ecuador 
Appendix 2. Guide to questions used during fieldwork. The questions in italics are the guide questions used with in the interviews conducted to the locals.

$\checkmark$ Did you ever know the dry forest in a completely natural state? Does this forest exist now? How would you describe it? How would you describe the best-preserved forest?

What is the best-preserved forest that you know in Zapotillo? For example, a forest where any other activity has took place in. Could you please provide an example of a specific site? Why do you believe that that forest is a good example of the best-preserved forest?

$\checkmark$ How is forest status changing since you first met it? How many forest states can you currently differentiate because of anthropogenic disturbance? How would you describe these states of forests in terms of their structure and composition (plant cover, plant diversity, regeneration, ecologic functioning, and soil conditions)?

Could you tell me what changes you have noticed in the forest? For example, are there sites that were only forests and are now used for timber, for grazing goats or for sowing?

Could you describe those sites? What plants are there? How are the trees (small, large, abundant, thin, etc.)?

Could you describe some characteristics that make those forests different from the best-preserved one?

$\checkmark$ How do you think that those changes in structure and composition of each forest state affect their ecological dynamics?

Do you think that those forest types have problems for their maintenance at long-term? Can you mention those problems that you have observed? For example, is the water quantity the same than in the best-preserved forest? Is the soil different? Are there any seeds?

$\checkmark \quad$ Which phase of the forest do you consider represent a phase at risk? Why?

What is the time of the year in which the forest is more susceptible to face those problems? Why?

What time in the year plants and trees suffer the most?. For example, when summer/winter begins, during the summer/winter, at the end of the summer/winter?

$\checkmark \quad$ What disturbance factors -drivers- do you think are causing changes in the structure and composition of the forest? Which of these drivers do you think are the main ones?

Can you mention the human activities that you considered are generating changes from a best-preserved forest to the other forest types?

$\checkmark$ How long (minimum of years - maximum of years) do you think the disturbance should be present to cause a transition -a change of state in the composition and structure of the forest-? 
Those sites that you mentioned as examples of other types of forest, how long they have been in the condition that we observe them currently? (The researcher provided examples of sites in each state of conservation, selected from those previously mentioned by the interviewee).

Thus, for a forest with the characteristics of the "best-preserved" forest to present the current appearance, it takes about ...... years, right?

$\checkmark$ Do you think that removing the disturbance would trigger a return to a previous state or not? In the case of affirmative answer, how many years do you consider are necessary to that return (minimum - maximum of years)? Under what management actions?

Do you think that if that forest (example of a forest state) were stopped using, it could recover to be a forest like that one it once was?

In the case of an affirmative answer, how many years do you consider necessary for that recover (minimum - maximum years)? What would be necessary for that recovery to take place-additional actions besides stopping using it-? 


\section{Appendix 3.}

Table A3.1. Characteristics of the forest states, actions behind the transitions and actions necessary for the recovery of the forests, obtained from the responses of ecologists and locals during the first round of interviews. The values into the ecologists and locals show the frequency of agrees with respect to the total number of interviewees during the member checking.

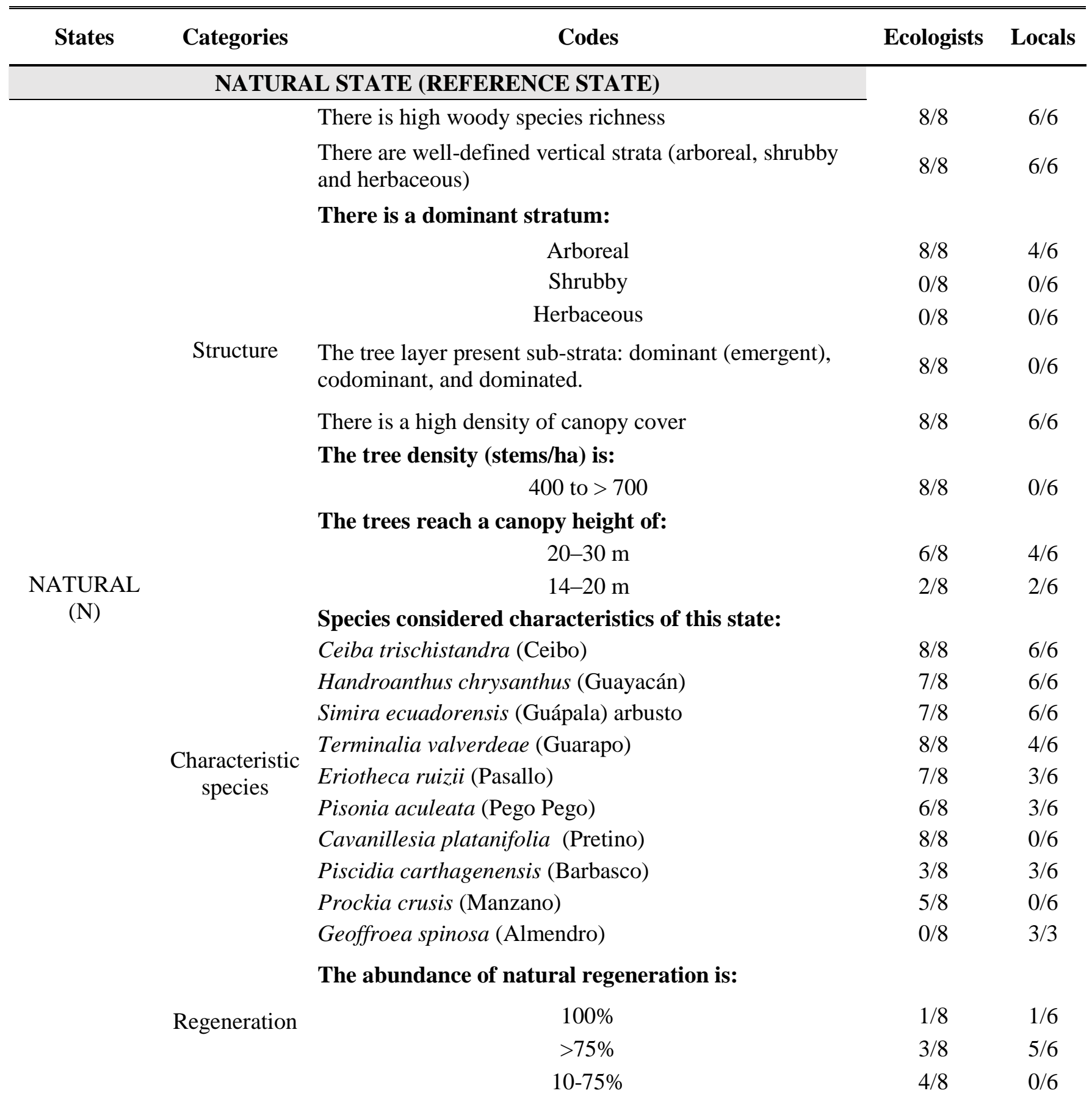


What soil characteristics do you consider adequate to describe this state?:

Soil High storage of seeds

$2 / 8 \quad 0 / 6$

Very fertile (recycling of nutrients)

$4 / 8 \quad 6 / 6$

Not very deep, it does not exceed $20 \mathrm{~cm}$.

$6 / 8$

$0 / 6$

\section{SEMI-NATURAL STATE}

\section{Compared to the $\mathrm{N}$ state the species richness is} reduced to:

$$
\begin{aligned}
& 70 \% \\
& 50 \%
\end{aligned}
$$

Change in coverage of the strata:

$$
\text { Arboreal }
$$

Shrubby

Herbaceous

Change in stratum composition:

Structure

$$
\text { Arboreal }
$$

Shrubby

$$
\text { Herbaceous }
$$

Compared to the $\mathbf{N}$ state, the density of canopy cover is:

SEMI-

NATURAL

$(\mathrm{sN})$

$$
\begin{gathered}
>75 \% \\
50-75 \%
\end{gathered}
$$

The tree density (stems/ha) is:

Reduction of emergent trees compared to the $\mathrm{N}$ state.

There is a canopy height of:

$$
\begin{aligned}
& 10-15 \mathrm{~m} \\
& 15-20 \mathrm{~m} \\
& 20-30 \mathrm{~m}
\end{aligned}
$$

Species considered as characteristic of this state.

Characteristic species
Handroanthus chrysanthus (Guayacán)

Simira ecuadorensis (Guapala)

Piscidia carthagenensis (Barbasco)

Ceiba trischistandra (Ceibo)

Cochlospermum vitifolium (Polo Polo)

Bursera graveolens (Palo Santo)

$8 / 8 \quad 6 / 6$

$8 / 8 \quad 6 / 6$

$8 / 8 \quad 6 / 6$

$7 / 8 \quad 6 / 6$

$7 / 8 \quad 0 / 6$

$8 / 8 \quad 0 / 6$


Croton sp.

$7 / 8$

$0 / 6$

Eriotheca ruizii (Pasallo)

Cavanillesia platanifolia (Pretino)

Ziziphus thyrsiflora (ébano)

$7 / 8 \quad 0 / 6$

$6 / 8 \quad 0 / 6$

$0 / 8 \quad 2 / 6$

Compared to the $\mathrm{N}$ state, the abundance of the natural regeneration is:

$\begin{array}{ccc}>75 \% & 2 / 8 & 0 / 6 \\ 75-50 \% & 5 / 8 & 4 / 6 \\ <50 \% & 1 / 8 & 0 / 6 \\ \text { to gaps recover } & 6 / 8 & 0 / 6\end{array}$

Compared to the $\mathbf{N}$ state, what proportion of species shows natural regeneration:

$\begin{array}{ccc}>75 \% & 2 / 8 & 1 / 6 \\ 75-50 \% & 6 / 8 & 4 / 6 \\ <50 \% & 0 / 8 & 0 / 6\end{array}$

What soil characteristics do you consider appropriate to describe this state?

Fertile but with trampling

$4 / 8$

$0 / 6$

Soil

Slight reduction in soil quality

$0 / 8$

$2 / 6$

Compared to the $\mathbf{N}$ state, the soil quality is:

$\begin{array}{ccc}>75 \% & 2 / 8 & 2 / 6 \\ 75-50 \% & 6 / 8 & 0 / 6 \\ <50 \% & 0 / 8 & 0 / 6\end{array}$

SHRUB-DOMINATED STATE

Compared to the $\mathbf{N}$ state, the species richness is reduced to:

$\begin{array}{lll}\geq 50 \% & 2 / 8 & 0 / 6 \\ <50 \% & 5 / 8 & 1 / 6 \\ <35 \% & 0 / 8 & 5 / 6\end{array}$

Change in coverage of the strata:

SHRUB

DOMINATED

(Sd)
Structure

The tree layer reduced to $50 \%$

The tree layer reduced to $<50 \%$

Trees may be isolated or absent

Large trees infrequent or absent

Increase of shrub and herbaceous strata

Increasing ground dominance by low shrubs (e.g.

Ipomoea carnea)

Increase in abundance of Cactus

Compared to the $\mathbf{N}$ state, the density of canopy cover is:
$2 / 8 \quad 0 / 6$

$6 / 8 \quad 6 / 6$

$7 / 8 \quad 0 / 6$

$6 / 8 \quad 0 / 6$

$6 / 8 \quad 6 / 6$

$7 / 8 \quad 0 / 6$

$0 / 8 \quad 3 / 6$ 


$$
\begin{gathered}
50-30 \% \\
<30 \%
\end{gathered}
$$

The tree density (stems / ha) is:

$$
100-150
$$

There is a canopy height of:

$$
<10 \mathrm{~m}
$$

Species considered characteristics of this state.

Acacia macracantha (Faique)

Chloroleucon mangense (Charán blanco)

Caesalpinia glabrata (Charán verde)

$6 / 8$

Cactaceas

$7 / 8$

$5 / 8$

$8 / 8$

$7 / 8$

$0 / 8$

$0 / 8$

$0 / 8$

$0 / 8$

$0 / 8$

Regeneration

There is very little regeneration in open areas.

The little regeneration is restricted to the base of the remaining trees

What soil characteristics do you consider appropriate to describe this state:

Soil

There is $20 \%$ organic matter compared to the $\mathrm{N}$ state

There is $10 \%$ organic matter compared to the $\mathrm{N}$ state

Alternating soil, areas with rocky soil and other areas with thin soil.

\section{ARID LAND STATE}

Compared to the $\mathbf{N}$ state, the richness of species is reduced to:

\section{ARID LAND}

(Al)

Structure
$6 / 8$

$$
0 / 6
$$

$7 / 8$

$$
6 / 6
$$

$7 / 8$

7/8

7/8

$0 / 6$

$4 / 8$

0/6

$1 / 8$

$0 / 6$

$7 / 8$

$2 / 6$

$4 / 6$

$2 / 6$

/6

$3 / 6$

$3 / 6$

$4 / 6$

0/6

$0 / 6$

$4 / 6$

$3 / 6$

$3 / 6$

$3 / 6$

$2 / 6$

$0 / 6$

0/6

$0 / 6$

$6 / 6$

$0 / 8$

$0 / 6$

$6 / 8$
$0 / 8$

$8 / 8$

The tree layer is reduced to: 
$0-5 \%$

$1 / 8$

$0 / 6$

The tree density (stems/ha) is reduced to:

$<20 \%$
$<10 \%$

$8 / 8$

$4 / 6$

$0 / 8$

$2 / 6$

The canopy height is:

$$
\text { 5-8 m }
$$

$6 / 8$

$0 / 6$

Species considered characteristics of this state.

Ipomoea carnea (borrachera)

Characteristic species

Acacia macracantha (Faique)

Cactaceas

Caesalpinia glabrata (Charán verde)

Bursera graveolens (Palo Santo)

Croton sp.

Compared to the $\mathrm{N}$ state, the abundance of natural regeneration is:

Regeneration

$$
\begin{gathered}
20-10 \% \\
<10 \%
\end{gathered}
$$

There is no regeneration

Indicate the percentage range in which you consider the soil's rockiness:

Soil

$$
\begin{gathered}
>90 \% \\
70-90 \%
\end{gathered}
$$

Bare and compacted soil

High runoff

Indicate the main action that you consider is generating transitions from one state to another.

Natural $\rightarrow$ Semi-natural

Semi-natural $\rightarrow$ Arid land

Semi-natural $\rightarrow$ Shrubdominated
Selective logging

Livestock browsing

Burning (for agriculture and livestock)

Disease called "fever"

Livestock browsing

Livestock and burning

Agriculture and burning

Livestock browsing

Burning (promote livestock fodder and agriculture)

Selective logging

Drought
$8 / 8$

$7 / 8$

$7 / 8$

$6 / 8$

$4 / 8$

$5 / 8$

$6 / 6$

$6 / 6$

$5 / 6$

$5 / 6$

$3 / 6$

$0 / 6$

0/8

$0 / 6$

$6 / 8$

$2 / 6$

$1 / 8$

$2 / 6$

$3 / 8$

$0 / 6$

$5 / 8$

$0 / 6$

$0 / 8$

$4 / 6$

$3 / 8$

$2 / 6$

$1 / 8$

$5 / 6$

$6 / 8$

$0 / 6$

$1 / 8$

$0 / 6$

$0 / 8$

$1 / 6$

$5 / 8$

$0 / 6$

$1 / 8$

$0 / 6$

$1 / 8$

$0 / 6$

$6 / 7$

$0 / 6$

$1 / 7 \quad 3 / 6$

$0 / 7 \quad 2 / 6$

$0 / 7$

$1 / 6$ 


\begin{tabular}{|c|c|c|c|}
\hline $\begin{array}{l}\text { Shrub-dominated } \rightarrow \\
\quad \text { Simplified }\end{array}$ & Exclude livestock & $3 / 7$ & $0 / 6$ \\
\hline \multirow{4}{*}{$\begin{array}{c}\text { Shrub-dominated } \rightarrow \text { Arid } \\
\text { land }\end{array}$} & Livestock browsing & $6 / 7$ & $0 / 6$ \\
\hline & Burning (promote livestock fodder and agriculture) & $1 / 7$ & $0 / 6$ \\
\hline & Soil processes disruption & $1 / 7$ & $0 / 6$ \\
\hline & Drought & $0 / 7$ & $1 / 6$ \\
\hline \multicolumn{4}{|c|}{$\begin{array}{l}\text { Indicate the years of disturbance (considering the current disturbance regime) that } \\
\text { can cause a change between states }\end{array}$} \\
\hline \multirow{5}{*}{ Natural $\rightarrow$ Semi-natural } & $25-50$ years & $0 / 8$ & $2 / 6$ \\
\hline & $15-20$ years & $0 / 8$ & $1 / 6$ \\
\hline & $10-14$ years & $6 / 8$ & $0 / 6$ \\
\hline & 5-9 years & $2 / 8$ & $0 / 6$ \\
\hline & $<5$ years & $0 / 8$ & $3 / 6$ \\
\hline \multirow{4}{*}{ Semi-natural $\rightarrow$ Arid land } & $>15$ years & $2 / 8$ & $0 / 6$ \\
\hline & $10-15$ years & $2 / 8$ & $0 / 6$ \\
\hline & $4-10$ years & $1 / 8$ & $0 / 6$ \\
\hline & $1-3$ years & $1 / 8$ & $0 / 6$ \\
\hline \multirow{5}{*}{$\begin{array}{c}\text { Semi-natural } \rightarrow \text { Shrub- } \\
\text { dominated }\end{array}$} & 50 years & $0 / 7$ & $1 / 6$ \\
\hline & 30 years & $0 / 7$ & $0 / 6$ \\
\hline & 20 years & $1 / 7$ & $1 / 6$ \\
\hline & $5-10$ years & $5 / 7$ & $1 / 6$ \\
\hline & $<5$ years & $0 / 7$ & $3 / 6$ \\
\hline \multirow{3}{*}{ Shrub-dominated $\rightarrow$ Arid land } & $5-10$ years & $0 / 7$ & $1 / 6$ \\
\hline & $\leq 5$ years & $4 / 7$ & $3 / 6$ \\
\hline & $<3$ years & $1 / 7$ & $2 / 6$ \\
\hline \multicolumn{4}{|c|}{$\begin{array}{l}\text { In the interview, you were asked about the actions necessary to recover an area of } \\
\text { dry forest (to return to a less altered state). Among the actions listed below, indicate } \\
\text { those that you consider most important. }\end{array}$} \\
\hline \multirow{4}{*}{ Semi-natural $\rightarrow$ Natural } & Exclude livestock & $7 / 8$ & $4 / 6$ \\
\hline & Tree planting & $1 / 8$ & $2 / 6$ \\
\hline & Logging control & $1 / 8$ & $0 / 6$ \\
\hline & Manually water & $0 / 8$ & $1 / 6$ \\
\hline \multirow{4}{*}{ Arid land $\rightarrow$ Semi-natural } & Exclude livestock & $4 / 8$ & $0 / 6$ \\
\hline & Soil recovery & $3 / 8$ & $0 / 6$ \\
\hline & Reforestation or enrichment of seeds (shrubs and trees) & $1 / 8$ & $0 / 6$ \\
\hline & Use of water retainer substances (hydrogel) & $2 / 8$ & $0 / 6$ \\
\hline
\end{tabular}


$\begin{array}{lll}\text { Exclude livestock } & 7 / 7 & 5 / 6\end{array}$

$\begin{array}{clrr}\begin{array}{c}\text { Shrub-dominated } \rightarrow \text { Semi- } \\ \text { natural }\end{array} & \text { Reforestation or enrichment with seeds } & 2 / 7 & 3 / 6 \\ \text { Manually water } & 0 / 7 & 1 / 6\end{array}$

$\begin{array}{lll}\text { Exclude livestock } & 7 / 7 & 3 / 6\end{array}$

\begin{tabular}{llrr} 
Arid land $\rightarrow$ Shrub-dominated & Reforestation with nurse or engineer plants & $2 / 7$ & $2 / 6$ \\
\cline { 2 - 2 } & Recovery of soils & $1 / 7$ & $0 / 6$
\end{tabular}

$\begin{array}{lll}\text { Manually water } & 0 / 7 & 1 / 6\end{array}$

Indicate the range of years that are required to restore a degraded state to a less

degraded one, after applying the restoration measures listed above:

\begin{tabular}{|c|c|c|c|}
\hline \multirow{4}{*}{ Semi-natural $\rightarrow$ Natural } & $>30$ years & $0 / 8$ & $1 / 6$ \\
\hline & 5-30 years & $3 / 8$ & $1 / 6$ \\
\hline & $5-10$ years & $4 / 8$ & $1 / 6$ \\
\hline & $3-25$ years & $1 / 8$ & $3 / 6$ \\
\hline \multirow{3}{*}{ Arid land $\rightarrow$ Semi-natural } & $50-100$ years & $2 / 8$ & $0 / 6$ \\
\hline & $>100$ years & $1 / 8$ & $0 / 6$ \\
\hline & Irreversible & $2 / 8$ & $0 / 6$ \\
\hline \multirow{4}{*}{$\begin{array}{c}\text { Shrub-dominated } \rightarrow \text { Semi } \\
\text { natural }\end{array}$} & $>50$ years & $1 / 8$ & $3 / 6$ \\
\hline & $20-30$ years & $1 / 8$ & $0 / 6$ \\
\hline & $>10$ years & $1 / 8$ & $1 / 6$ \\
\hline & $\leq 5$ years & $0 / 8$ & $1 / 6$ \\
\hline \multirow{4}{*}{ Arid land $\rightarrow$ Shrub-dominated } & Irreversible & $2 / 8$ & $0 / 6$ \\
\hline & $50-100$ years & $0 / 8$ & $1 / 6$ \\
\hline & $30-50$ years & $1 / 8$ & $2 / 6$ \\
\hline & 10 years & $0 / 8$ & $1 / 6$ \\
\hline \multicolumn{4}{|l|}{ Risk phase } \\
\hline \multirow{2}{*}{ Dry season } & $\begin{array}{l}\text { Period when selective logging, goat ranching and burning } \\
\text { intensify. }\end{array}$ & $3 / 8$ & $0 / 6$ \\
\hline & $\begin{array}{l}\text { Vulnerability to extreme drought events, which cause } \\
\text { death of trees and low regeneration. }\end{array}$ & $0 / 6$ & $6 / 6$ \\
\hline Rainy season & $\begin{array}{l}\text { At the beginning of this season, local people burn areas to } \\
\text { prepare them for cultivation }\end{array}$ & $3 / 8$ & $0 / 6$ \\
\hline $\begin{array}{l}\text { The transition between dry } \\
\text { and rainy season }\end{array}$ & $\begin{array}{l}\text { Many species disperse their seeds and germinate during } \\
\text { or at the end of the rainy season, thus, the presence of } \\
\text { browsing livestock in that period causes a high mortality } \\
\text { of seedlings. }\end{array}$ & $2 / 8$ & $0 / 6$ \\
\hline
\end{tabular}

